\title{
Hvad stiller man op med fejlslagne stater? Louise Andersen
}

Er det rigtigt at tage for givet, at fejlslagne stater kan og skal genskabes som levedygtige selvstændige enheder? Eller vil det være mere virkningsfuldt at oprette internationalt styrede protektorater eller helt modsat - slet ikke at blande sig?

Efter de neo-liberale 1980'ere og 90'ere, hvor begrænsning af statens rolle stod højt på den udviklingspolitiske dagsorden, er pendulet svinget i den stik modsatte retning. I dag handler det om at styrke staterne. Om at sikre, at de er i stand til at løse de opgaver, det internationale samfund og deres borgere forventer af dem. Eller som FN's generalsekretær, Kofi Annan, for nylig udtrykte det: "One of the greatest challenges of the new millennium is to ensure that all states are strong enough to meet the many challenges they face."

Tendensen var på vej allerede før 11. september 2001, men al-Qaidas husly hos Taliban-regimet i Afghanistan satte ekstra fart i pendulet. Kampen mod terrorisme er også blevet en kamp imod svage og fejlslagne stater. Allerede få uger efter terrorangrebene på USA, hævdede den daværende leder af FN's udviklingsprogram, at "the real lesson of 9-11 is that states don't have the right to fail”. Året efter fastslog præsident Bush i sin nationale sikkerhedsstrategi, at "America is now threatened less by conquering states than we are by failing ones.” Og i 2003 fulgte EU trop med sin egen - og første - sikkerhedsstrategi, hvor fejlslagne stater identificeres som en af de fem største trusler, Europa og den øvrige verden står overfor i dag.

Koblingen mellem sikkerhed og udvikling er dermed blevet endnu stærkere. Det gælder både i den forstand, at vi i den vestlige verden betragter 'vores' sikkerhed som afhæn- 
gig af 'deres' udvikling i den tredje verden. $\mathrm{Og}$ i den forstand, at sikkerhed ses som en helt afgørende forudsætning for udvikling. Voldelige konflikter får udviklingen til at køre i bakgear, som Verdensbanken udtrykker det.

Denne strategiske trekant - sikkerhed, udvikling og svage stater - har ført til et skifte i den udviklingspolitiske diskussion. Opmærksomheden er ikke længere forbeholdt de såkaldt gode performere med stærke institutioner og fornuftige politikker, hvor man får mest udvikling pr. bistandskrone. I stedet er fokus rettet mod de allersvageste lande. Lande, hvor regeringen ikke er i stand til at skabe sikkerhed og lov og orden - langt mindre gennemføre politiske og økonomiske reformer for at bekæmpe fattigdommen. Lande som Afghanistan, Sierra Leone, Liberia og den Demokratiske Republik Congo.

Sådanne lande udgør et problem. Og vel at mærke et problem, de vestlige lande føler, de ikke længere kan tillade sig at ignorere. Men rådvildheden er stor. Det internationale samfund aner groft sagt ikke, hvad det skal stille op med disse stater. Noget skal gøres. Men hvad?

Den politiske diskussion om hvad man skal gøre med fejlslagne stater er interessant både pga. alt det, der bliver sagt, og pga. alt det, der ikke bliver sagt. På den ene side er diskussionen bemærkelsesværdig åbenhjertig og selvkritisk. Den sætter fingeren på en række af det internatio- nale samfunds ømmeste punkter. På den anden side tager diskussionen for givet, at fejlslagne stater kan og skal genskabes som levedygtige selvstændige stater. Og at det internationale samfund bør og kan bidrage til den proces. Alternative og mere radikale løsningsmodeller - som fx at oprette internationale protektorater eller helt undlade at blande sig indgår ikke for alvor i debatten. De er dog værd at se nærmere på alligevel, fordi de sætter tingene på spidsen og dermed synliggør nogle af de dilemmaer og paradokser, det internationale samfund står overfor.

For indledningsvist at skabe en fælles forståelse af, hvilken type stater det egentligt er vi taler om, vil selve begrebet fejlslagen stat blive belyst nedenfor, inden blikket vendes mod diskussionen af de forskellige løsningsmodeller.

\section{Hvad er en fejlslagen stat?}

Hverken politisk eller akademisk er der enighed om, hvad en fejlslagen stat er. Begrebet bruges forskelligt af forskellige mennesker - og forveksles af nogle fejlagtigt med såkaldte slyngelstater. I denne artikel er betegnelsen fejlslagen stat forbeholdt lande, hvor centralregeringen er mere eller mindre kollapset og har mistet kontrollen med store dele af landet. Det er lande som Afghanistan, den Demokratiske Republik Congo, Haiti, Liberia, Sierra Leone, Salomon øerne og Somalia. 
I den udviklingspolitiske diskussion fokuseres ofte på en bredere gruppe af stater: De såkaldte svage stater, hvor regeringen enten ikke kan eller vil varetage de funktioner, der normalt forbindes med moderne stater. I følge den britiske udviklingsorganisation, DFID, er der 46 sådanne skrøbelige stater i verden $\mathrm{i}$ dag. Det er - ud over ovennævnte lande - også lande som Angola, Burma, Cambodja, Georgien, Indonesien, Kirgisistan, Laos, Usbekistan og Zimbabwe. Fejlslagne stater udgør i den sammenhæng den ene yderpol på et kontinuum over staters 'styrke' - eller rettere staters 'svaghed'. Det diskuteres sjældent præcis, hvad der ligger i den anden yderpol, men de fleste går ud fra, at det er velfungerende og stærke stater som Danmark.

Fejlslagne stater er først og fremmest kendetegnet ved, at den centrale regeringsmagt ikke har kontrol over territoriet og ikke har monopol på voldsmidlerne. Derudover har de det tilfælles med andre svage stater, at de ikke leverer de helt basale ydelser, som moderne stater typisk forventes at levere til befolkningen. Det vil først og fremmest sige sikkerhed samt lov og orden, og i anden omgang sociale ydelser som sundhed og uddannelse.

Levevilkårene i fejlslagne stater er meget ringe. Der er udbredt og ekstrem fattigdom, sult og fejlernæring. Ofte er over $70 \%$ af befolkningen underernæret. Gennemsnits- levealderen er meget lav - fx 34,3 år i Sierra Leone. Børnedødeligheden er meget høj, og store dele af befolkningen har ikke adgang til rent vand. Den alvorlige humanitære situation er dog ikke det afgørende karakteristikum eller det forhold, der politisk og akademisk er fokus på. Det er derimod sikkerhedssituationen.

Fejlslagne stater er som regel præget af omfattende vold, kriminalitet og brutalitet. Stater, hvor rivaliserende krigsherrer og forskellige former for bevæbnede grupper hersker lokalt og kæmper om kontrollen med befolkningen, territoriet og økonomien. Fx strides helt op mod 50 grupper indbyrdes og i forskellige alliancer om magten alene i Ituri-regionen i det nordøstlige Congo.

Fejlslagne stater er typisk stater, hvor en borgerkrig er løbet løbsk og har udviklet en selvforstærkende krigsøkonomi, hvor ingen af de krigende parter har reel interesse $\mathrm{i}$ fred, fordi deres adgang til magt, ressourcer og indflydelse afhænger af fortsat ustabilitet og uorden. Ikke af fred. For krigsherrer og lokale militser vil produktion og salg af varer som fx narkotika, diamanter eller ædeltræ typisk være langt mere indbringende end en hvilken som helst ministerpost i en overgangsregering efter en fredsaftale.

I det ekstreme tilfælde af en fejlslagen stat - Somalia - er der slet ingen regering i landet. I andre tilfælde eksisterer der fortsat en formel 
regering, der typisk kun har kontrol med hovedstaden og området omkring den - og ofte kun om dagen. Om natten hersker lovløsheden. Og ofte adskiller regeringen og dens væbnede styrker sig ikke fra de private militære grupper mht. brutalitet og kriminalitet. Overgreb på civilbefolkningen sker både fra regeringsstyrker, oprørsbevægelser og almindelige kriminelle bander.

\section{Stat eller ikke-stat}

I fejlslagne stater giver det kun ringe mening at sondre mellem stat/ikkestat. I det omfang staten fortsat fungerer, tjener den typisk kun et lille mindretals interesser - som regel en mere eller mindre diktatorisk leder og eliten inden for hans etniske gruppe, klan eller religiøse samfund.

Denne privatisering af staten er typisk sket over en årrække - og meget ofte med slet skjult støtte fra udlandet. Et af de grelleste eksempler er Zaïres enehersker Mobuto, der under den kolde krig blev holdt ved magten som et bolværk mod kommunismen, samtidig med han meget effektivt tømte staten for ressourcer og kapacitet.

I de sidste år af Mobutos styre gik langt over $90 \%$ af statsbudgettet til hans personlige hof, mens der ingen penge overhovedet blev brugt på social- og sundhedssektoren.

I takt med, at stater som Zaïre (nuværende Demokratisk Republik
Congo) er blevet udhulet indefra og har mistet deres statslighed, har forskellige andre grupper i varierende grad påtaget eller tilranet sig opgaver, der ellers normalt forbindes med staten. Sikkerhed og beskyttelse leveres af private grupperinger ofte mod betaling. Uformelle justitssystemer opretholdes af traditionelle ledere eller lokale stærke mænd. Forskellige former for skat inddrives af kriminelle bander, der samtidig kontrollerer den sorte $\varnothing$ konomi. Og sociale ydelser som uddannelse og sundhed leveres af private aktører ofte mod betaling eller som velgørenhed.

Fejlslagne stater er derfor ikke tomme anarkier, hvor kun kaos råder. Tværtimod er de ofte præget af en mangfoldighed af uformelle, overlappende og ofte modstridende politiske, økonomiske og sociale strukturer, institutioner og netværk, der på godt og ondt regulerer den lokale befolknings liv og adfærd.

Set i det perspektiv er 'fejlen' ved fejlslagne stater, at de ikke fungerer ligesom almindelige stater. De ligner ikke de moderne centraliserede stater, der har udviklet sig i Europa siden den westfalske fred i 1648, og som siden er blevet den globale norm for, hvordan en suveræn stat skal se ud.

Fejlslagne stater minder snarere om de komplekse og diffuse magtstrukturer, der prægede Europa i Middelalderen; før de enevældige konger fik magten samlet omkring 
sig selv i hovedstaden. Det er derfor til en vis grad både ahistorisk og eurocentrisk at betegne nogle lande som fejlslagne. Det er i forhold til vores målestok, de er fejlslagne.

Kritikken er berettiget, men må ikke fjerne opmærksomheden fra, at de alternative autoritetsformer, der findes i fejlslagne stater, ikke er i stand til at sikre befolkningen et godt liv. Omvendt skal man ikke være blind for, at det var de strukturer, der fandtes før sammenbruddet, heller ikke.

Hovedparten af de stater, der i dag betragtes som fejlslagne, har aldrig været i noget der ligner nærheden af at fungere som moderne (velfærds)stater. Uanset hvilke trusler, man udefra set forbinder med svage og fejlslagne stater, er det først og fremmest den lokale befolkning, det går ud over - både før og efter en stat bryder sammen under vægten af overdreven korruption, magtmisbrug og brutalitet.

Efter det internationale samfund er begyndt at interessere sig for dette som andet end et humanitært og lokalt problem, er der kommet øget opmærksomhed om behovet for at gøre noget. Og vel at mærke noget effektivt. Noget, der både kan skabe rammen om en bedre fremtid for befolkningen og bekæmpe de trusler, især den vestlige verden forbinder med svage og fejlslagne stater: organiseret kriminalitet og terrorisme. Dette 'noget' er emnet for det næste afsnit.

\section{Peacebuilding Commission}

Den generelle politiske diskussion om, hvad det internationale samfund skal stille op med de svage stater, foregår blandt andet i OECDregi - dvs. blandt den vestlige kreds af donorlande, der tegner sig for over $90 \%$ af den officielle udviklingsbistand i verden. Spørgsmålet optager dog også sindene i $\mathrm{FN}$, hvor det ses som en del af de udfordringer, der nødvendiggør reformer af organisationen. Generalsekretæren har således foreslået, at der etableres en særlig Peacebuilding Commission, der skal koordinere den internationale støtte til genopbygning af konfliktramte og sammenbrudte stater.

Generalsekretærens forslag ventes at indgå i den samlede reformpakke, som FN's medlemslande skal tage stilling til på Verdenstopmødet i New York til september. I forberedelse af topmødet drøfter man i øjeblikket detaljerne omkring Kommissionen. Centrale spørgsmål som fx Kommissionens mandat og dens sammensætning er endnu ikke på plads. Danmark og de øvrige EUlande støtter Generalsekretærens forslag og ser gerne, at Kommissionen bliver så stærk som muligt.

Etablering af en Peacebuilding Commission falder godt i tråd med det større og mere samlede internationale engagement i svage og fejlslagne stater, som donorlandene i OECD plæderer for. Behovet for at gøre mere - og for at gøre det bedre 
- løber som en rød tråd gennem diskussionen. Og selvom donorerne naturligvis er omhyggelige med ikke at pege fingre ad hinanden, lægger de ikke fingre imellem, når den generelle indsats i skrøbelige stater skal bedømmes. Hjælpen har været for lille, for dårlig og forkert. De svage stater har ikke alene modtaget langt mindre bistand end andre fattige lande. De har også modtaget dårligere og meget mere svingende bistand. Støtten er blevet givet til små, løsrevne og kortvarige projekter, der ikke for alvor har ændret noget. Og donorerne har oven i købet ofte skruet op og ned for bistandshanen fra år til år og dermed gjort det endnu vanskeligere for landet at få en langsigtet og sammenhængende udviklingsstrategi.

Billedet understreges af studier fra Verdensbanken, der også viser, at det især er de bilaterale donorer, der har svigtet de svageste stater. FN-organisationerne har været mere vedholdende i deres støtte til de svage stater.

Manglende koordination af indsatsen, uhensigtsmæssig konkurrence mellem forskellige donorer og modstridende målsætninger mellem forskellige dele af det internationale samfund har ikke bare ført til dobbeltarbejde og spild af knappe ressourcer. Nogle gange har det decideret været med til at forværre situationen. Det internationale samfund har alt for ofte været drevet af en jagt på hurtige løsninger, hvor ambitiøse målsætninger om at hjælpe krigshærgede samfund på fode igen skulle realiseres i løbet af meget kort tid. Som regel i løbet af to år, hvorefter der kunne afholdes frie valg, og en evt. international fredsstyrke kunne trækkes tilbage.

Og selvom det internationale samfunds civile engagement typisk fortsætter, efter soldaterne er rejst hjem, har det meget ofte været hastigt aftagende - både målt i kroner og ører og i politisk opmærksomhed.

\section{Principper for god indblanding}

På baggrund af denne kritiske diskussion har OECD i foråret 2005 vedtaget en række principper for 'godt internationalt engagement i skrøbelige stater'. Principperne skal ideelt set sikre en langsigtet og sammenhængende indsats, hvor civile og militære, private og statslige, multilaterale og bilaterale aktører trækker på samme hammel. Og dermed også i samme retning.

Principperne er ikke bindende, og der er ingen kontrolmekanismer, der kan sikre, at de bliver efterlevet. Alene derfor er der ikke særlig grund til at forvente, at de vil rykke afgørende ved engagementet $\mathrm{i}$ skrøbelige stater. Det interessante ved principperne er altså primært det vidnesbyrd, de giver om, hvordan de vestlige lande opfatter problemet, og hvilke mulige løsninger de ser. Og her er der især ét ord, der gennemsyrer dokumentet. Det ord er statsbygning. 
Den langsigtede vision er at hjælpe nationale reformkræfter med at opbygge legitime, effektive og robuste statsinstitutioner. Etablering af levedygtige suveræne stater er det centrale formål med indsatsen. $\mathrm{Og}$ det skal ske gennem støtte til tre søjler: 1) statens evne til at varetage basale kernefunktioner inden for sikkerhed, lov og orden og sociale ydelser, 2) statens legitimitet og ansvarlighed og 3) statens evne til at skabe rammerne for økonomisk vækst.

Det betyder ikke, at al bistanden skal gives til staten. Det kan være nødvendigt - $\mathrm{fx}$ inden for det sociale område - at arbejde med ikke-statslige aktører. Men støtten skal gives på en måde, der sikrer, at man ikke opbygger parallelle strukturer eller på anden måde er med til at underminere staten.

For at dette kan resultere i varig afsked med fattigdom og usikkerhed skal processen drives af den lokale befolkning og deres ledere. Dette er et almindeligt sundt princip, der ligger til grund for al god udviklingsbistand. Særligt i svage og fejlslagne stater kan det være svært at omsætte princippet til praktisk handling.

OECD lægger derfor op til, at donorerne selv styrer processen og skaber sammenhæng i de lande, hvor regeringen ikke er i stand til det. De internationale aktører skal arbejde meget tættere sammen end hidtil og så at sige koordinere sig selv og hinanden. Målsætningen om, at processen skal være drevet af den lokale befolkning - anført af regeringen i hovedstaden - er dog ikke glemt. Tværtimod er det et mål i sig selv så hurtigt som muligt at sikre, at nationale - dvs. landsdækkende - institutioner tager ansvar for den samlede udvikling inden for landets grænser.

Både Generalsekretærens forslag om en Peacebuilding Commission og OECD's principper for godt internationalt engagement i skrøbelige stater fokuserer på genopbygning - dvs. på en mere eller mindre udtalt forestilling om, at staterne tidligere har fungeret som sammenhængende og selvstændige enheder.

For en stor del af de fejlslagne stater kan der stilles ganske store spørgsmålstegn ved, om det er tilfældet. Som regel er der tale om stater, hvis uafhængighed (i nyere tid) stammer fra afviklingen af de europæiske kolonier efter Anden Verdenskrig eller fra Sovjetunionens opløsning efter 1989. Blandt andet derfor er det politisk meget ømtåleligt at gå ind i en diskussion af, om disse stater i det hele taget er bæredygtige som selvstændigheder enheder - eller hvad der skal til for, at de kan blive det. I den akademiske diskussion om fejlslagne stater er sådanne spørgsmål langt mindre tabubelagt.

\section{To alternative løsninger}

På samme måde som man kan forestille sig et kontinuum af gradvist svagere stater, kan man forestille sig 
et kontinuum af gradvist mere indgribende international indblanding. I hver ende af kontinuumet befinder sig to vidt forskellige løsningsforslag. Den ene mulighed er, at det internationale samfund ingenting gør - at man helt undlader at blande sig, og på godt og ondt lader tingene gå deres skæve gang. Den anden mulighed er, at det internationale samfund påtager sig kontrollen og ansvaret $-\mathrm{fx}$ gennem etableringen af internationale protektorater.

Selvom begge muligheder ligger lige under overfladen i den aktuelle diskussion, er der ingen af dem, der for alvor drøftes politisk. Etableringen af protektorater er uacceptabel for mange af FN's medlemslande enten fordi forslaget bringer mindelser om kolonitiden eller fordi det forpligter til at afsætte langt flere ressourcer. Omvendt er der (jf. ovenfor) en stor og magtfuld gruppe lande, der finder, at det internationale samfund har både en moralsk forpligtelse til og en egennyttig interesse i at blande sig. Det internationale samfund kan ikke bare lade stå til, mens stater bryder sammen. Set på den baggrund er det ikke overraskende, at den aktuelle policy-diskussion befinder sig et sted mellem disse to yderpunkter.

Bag diskussionen om, hvad det internationale samfund skal stille op med fejlslagne stater, ligger en diskussion om internationale normer og universelle værdier. Når tingene sættes på spidsen, træder dilemmaerne, paradokserne og de uundgåelige trade-offs tydeligere frem. Alene af den grund er det interessant at se nærmere på forslagene om enten at ophæve fejlslagne staters suverænitet eller at respektere princippet om ikke-indblanding fuldt ud. Derved kastes lys over forhold, der let forsvinder i en mere politisk korrekt diskurs.

\section{Internationale protektorater}

For bare få år siden var ideen om at sætte nogle landområder under internationalt formynderskab og etablere protektorater eller mandatområder nærmest uhørt. De tidligere kolonier havde vundet en umistelig ret til uafhængighed og selvbestemmelse, da de blev anerkendt af det internationale samfund som suveræne og ligeværdige stater. At forestille sig, at de skulle miste denne ret igen, var helt utænkeligt.

Tværtimod var deres overlevelse og fortsatte eksistens som suveræne stater garanteret af det internationale samfund - både gennem den stringente insisteren på grænsernes ukrænkelighed og gennem princippet om ikke-indblanding $\mathrm{i}$ indre anliggender.

Efter den kolde krigs afslutning er begge principper blevet modificeret. En række nye stater - og dermed nye grænser - er blevet anerkendt (om end kun efter udtrykkelig accept fra 'moderlandet'), og hensynet til menneskerettighederne tillægges stadig større vægt på bekost- 
ning af statens ret til ikke-indblanding. Opfattelsen af suverænitet er med andre ord blevet mere mudret.

Suverænitet er ikke kun en negativ ret forbundet med statens frihed, det er også en positiv pligt forbundet med statens ansvar. Statens ansvar udlægges i denne diskurs oftest som ansvaret for at opretholde lov og orden inden for sit territorium og skabe ordentlige levevilkår for befolkningen.

Det er i dette lys, forslag om at ophæve fejlslagne staters suverænitet og sætte dem under international administration skal ses. En stat, der vedholdende og groft ikke lever op til sit ansvar, fortaber retten til sin frihed - om ikke for evigt, så for en længere periode. Det internationale samfund må påtage sig ansvaret, skabe lov og orden og sikre befolkningen ordentlige levevilkår. Og det tager tid - måske flere generationer.

I én forstand kan dette ses som en sejr for de universelle menneskerettigheder. Ved at gribe ind tilsidesætter det internationale samfund hensynet til statens rettigheder og holder i stedet individets rettigheder $\mathrm{i}$ hævd. Det internationale samfund gør sig selv til garant for, at den lokale befolkning kan leve et liv i sikkerhed, værdighed og frihed. Eller gør det? Kan man leve et liv i frihed og værdighed uden ret til selvbestemmelse og under administration af folk udefra? Problemstillingen er højaktuel i forhold til diskussionen om Kosovos endelige status.

\section{Ikke-intervention}

Som bekendt kan det internationale samfund gribe ind uden at tilsidesætte statens suverænitet. Den statsbygnings-strategi, der pt. har megen medvind i diskussionen, bygger på en blanding af internationalt engagement og nationalt ejerskab og ansvar. En slags hjælp til selv-hjælp. Det ses fx tydeligt i Afghanistan, hvor man bevidst har undladt at etablere en international overgangsadministration, som man $\mathrm{fx}$ gjorde $\mathrm{i}$ Øst-Timor. Det formelle ansvar ligger hos regeringen i Kabul. Det er dens planer og politikker, det internationale samfund støtter.

At regeringens reelle indflydelse endnu ikke rækker langt uden for hovedstaden er ikke afgørende i den forbindelse. Tværtimod er formålet jo netop at sikre, at Kabul-regeringen får kontrol med hele landet.

Det skorter dog ikke på advarsler om, at det er en grundlæggende forfejlet strategi, man har valgt. Afghanistan har historisk set altid været en stat med meget stærke regionale ledere og en forholdsvis svag hovedstad - paradoksalt nok var Taliban-styret et af de få regimer, der formåede at opnå en vis kontrol med hele landet og fx slå effektivt ned på opium-produktionen. At ændre ved sådanne traditionelle og indgroede forestillinger om, hvordan magten skal fordeles, er mildest talt op ad bakke. Og at forsøge at gøre det udefra - om end under dække af støtte til en mario- 
net-regering - er stort set umuligt. Statsbygning er en intern proces, hvor eksterne aktører meget nemt risikerer at gøre mere skade end gavn.

Det er den type argumentation, der ligger bag forslag om, at det internationale samfund skal undlade at intervenere i fejlslagne stater. Det bedste man kan gøre udefra er at vente og se, hvilken form for politisk organisering der udmønter sig lokalt, og så acceptere den. Måske også selvom det indebærer løsrivelse og anerkendelse af nye territoriale grænser. Fx argumenterer mange for at opgive illusionen om, at Somalia skal fungere som ét sammenhængende land. Områder som Somaliland, der reelt har løsrevet sig og fungerer som selvstændige enheder, bør anerkendes som sådan internationalt.

Det internationale samfunds tilbagevendende forsøg på at mægle, slutte fred og forsøge at få mere eller mindre kunstige overgangsregeringer til at fungere kan meget vel risikere at legitimere volden, holde liv i konflikterne og udskyde muligheden for at opnå en egentlig fredsløsning, der er forankret og accepteret lokalt. Omverdenen kan med en vis rimelighed gå ud fra, at alle mennesker ønsker at leve et nogenlunde fredeligt liv.

Men det internationale samfund kan ikke vide, om bosnierne ønsker at leve i en stat, der er multietnisk, eller om afghanerne ønsker en sekulær stat. Derfor skal det internationale samfund undlade at blande sig og i stedet overlade det til de lokale selv at finde en løsning - og så naturligvis acceptere de regimer og enheder, der med tiden viser sig.

Argumentet er først og fremmest en advarsel om, at man ikke skal presse 'fremmede' løsninger ned over hovedet på andre folkeslag og kulturer. Men hvor langt kan og vil man gå i accepten af, at alle samfund er ligeværdige og har retten til selv at finde egne løsninger på egne problemer? Hvordan forholder man sig til lokale løsninger, der grundlæggende strider med de værdier og normer, der betragtes som universelle? Er der faktisk samfund og kulturer, menneskerettighederne ikke passer til? Eller handler det 'bare' om, at rettigheder ikke er noget, et samfund kan få foræret udefra, men noget det selv må kæmpe for?

\section{Hvad med fremtiden?}

Som det var tilfældet med forslaget om etablering af internationale protektorater, viste diskussionen om helt at undlade at blande sig hurtigt at handle om respekten for menneskerettighederne. Dette er ikke overraskende, da en stor del af problemet med svage og fejlslagne stater netop er, at de ikke garanterer befolkningens rettigheder. Den internationale opmærksomhed retter sig dog mindst lige så meget mod et andet aspekt: de forskellige illegale netværk, der trives i svage og fejlslagne stater. Netværk, der forbindes 
med alle former for organiseret kriminalitet og med international terrorisme.

I forhold til den problemstilling giver forslaget om ikke at blande sig kun mening, hvis man kan være sikker på, at der forholdsvis hurtigt af sig selv etableres en lokal ledelse, der kan og vil bekæmpe de illegale netværk. Det er der ikke meget, der tyder på, at man kan.

Derimod virker forslaget om at etablere internationale protektorater alt andet lige som et attraktivt og effektivt middel i kampen mod de illegale netværk. I stedet for langsomt og møjsommeligt - gennem hjælp til selvhjælp - at opbygge lokal kapacitet til at sikre lov og orden, kan det internationale samfund selv påtage sig ansvaret og kontrollen. I hvert fald for en stund.

Meget tyder da også på, at det er i den retning, diskussionen flytter sig. Generalsekretærens forslag om en Peacebuilding Commission kan tolkes som et forsøg på at genoplive Formynderrådet - uden at give mindelser om kolonitiden. Og OECD's principper for godt internationalt engagement lægger op til en langt stærkere, mere koordineret og mere langvarig international indsats i skrøbelige stater. Paradoksalt nok kan svage stater således føre til et stærkere internationalt samfund.
Helt afgørende for om det sker, vil selvfølgelig være den måde, policydiskussionerne udmønter sig i konkrete handlinger og reelle ændringer af opførslen 'on the ground'. Mange af de pointer, der understreges, er gammel vin på nye flasker, og det er klart, at man ikke må forveksle pæne hensigtserklæringer i skåltaler og strategier med virkeligheden.

Det afgørende er ikke, at stater, der tidligere var betydningsløse frynser i udkanten af det globale tæppe, nu står højt på den internationale dagsorden. Det interessante er, om udfordringerne fra disse stater besvares på en måde, der piller ved selve tæppet - ved de normer, der binder det internationale samfund sammen: Hvordan skal forholdet fx være mellem ikke-intervention, selvbestemmelse og menneskerettigheder, og hvad betyder 'suverænitet' i det 21. århundrede?

Det er store spørgsmål som disse, der skal besvares undervejs i fors $\varnothing$ get på at sikre, at alle stater er stærke nok til at møde de udfordringer, de stilles overfor.

Louise Andersen er fuldmegtig i Udenrigsministeriet og sekunderet til Dansk Institut for Internationale Studier $i$ 2004-2006. 